\title{
"Syndrome of contractures and deformities" according to Prof. Hans Mau as the primary cause of motoric deformities in children. Case studies including deformities of hips, neck, shank and spine
}

\author{
Karski Jacek ${ }_{\mathrm{A}, \mathrm{B}, \mathrm{C}, \mathrm{D}, \mathrm{E}, \mathrm{F}, \mathrm{G}}$, Karski Tomasz $_{\mathrm{A}, \mathrm{B}, \mathrm{C}, \mathrm{D}, \mathrm{E}, \mathrm{F}, \mathrm{G}}$
}

${ }^{1}$ Paediatric Orthopaedic and Rehabilitation Department of Medical University of Lublin, Poland, ${ }^{2}$ Vincent Pol University of Lublin, Poland

\section{Summary}

Authors claim that the problem of deformities in children and pain in adult patients can be connected to shortening of soft tissues followed by contractures of joints. The „syndrome of contractures” (SofC) described by Prof. Hans Mau - as "Syndrome of seven contractures", explains influence of the foetal position during pregnancy to future asymmetrical contractures of multiple joints (an infantile scoliosis, torticollis, limitation of abduction of left hip, feet deformations). The "left sided syndrome of contractures" is more common, since $85 \%-95 \%$ of pregnancies are cephalic presentations, first position pregnancies.

In years 2005 - 2013 authors examined 818 new-borns and infants with SofC. The control group was 212 healthy children, without signs of the SofC.

Analysis of the material confirmed the presence of syndrome of contracture signs described by Prof. Mau. Effective treatment of children with SofC is possible and it should be used as prophylaxis of future insufficiency of movement of knees, hips and spine in adult age.

Key words: syndrome of contracture, weak posture, torticollis

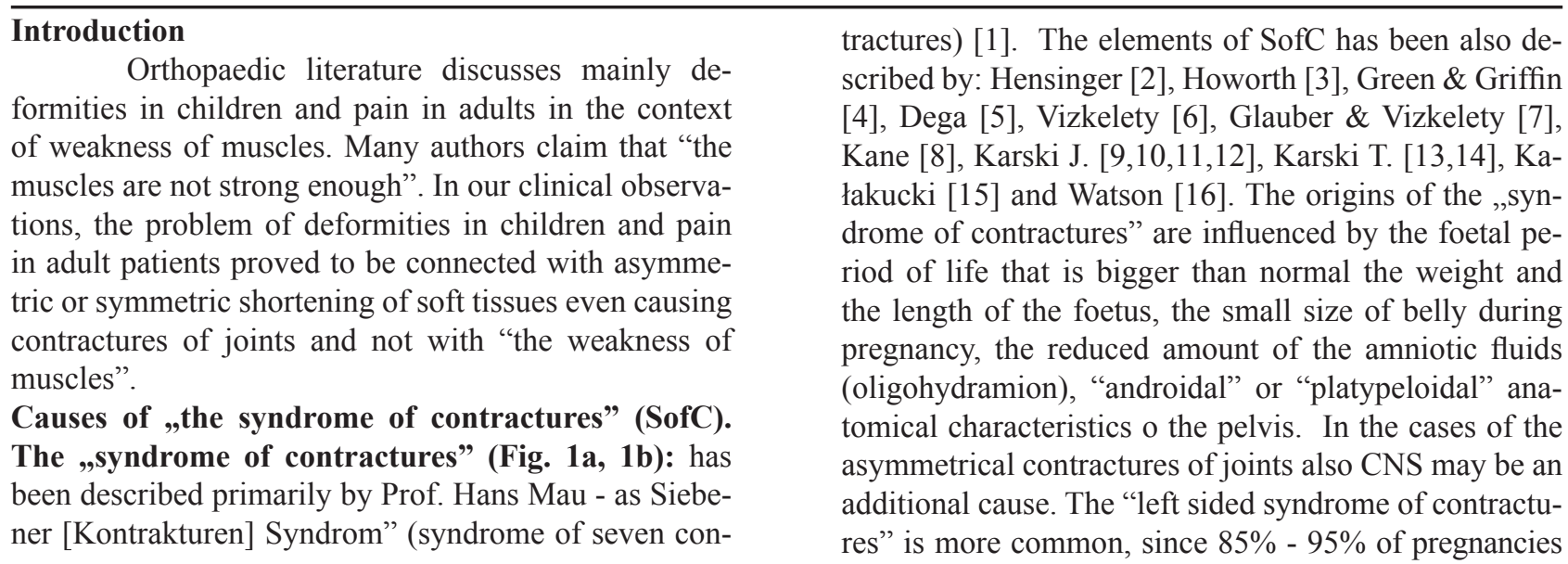

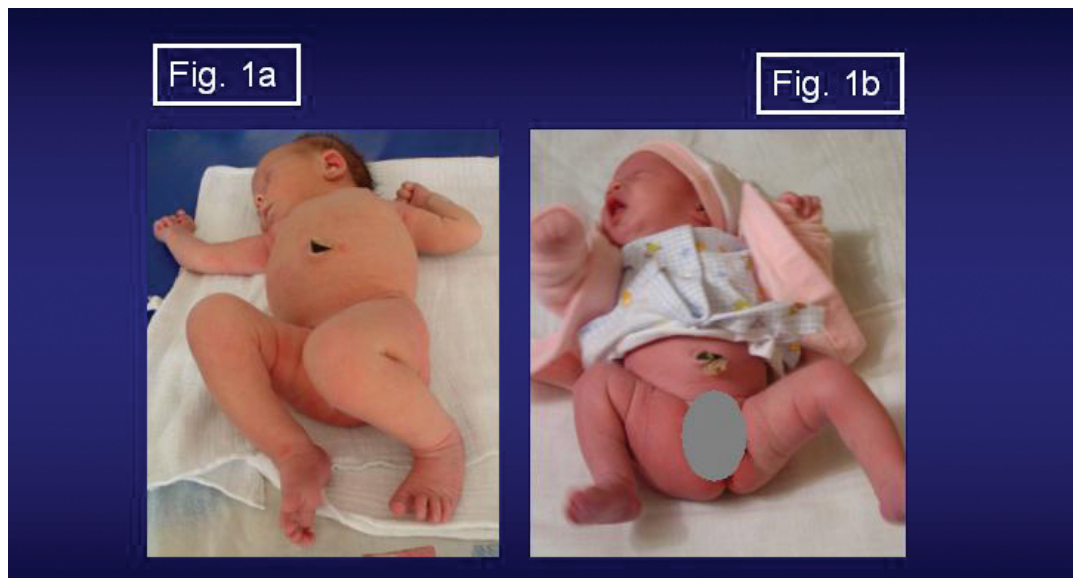

Fig. 1a. 1b. Typical clinical symptoms of „Syndrome of contractures and Deformities” in newborns and babies

Fig. 1b. Asymmetries in head, neck, spine, hips (later dysplasia), pelvis. „Haltungschwäche according to Hans Mau is equal to the abduction contracture and often external-rotation and flexion contractures of the right hip according T. Karski (1995 - 2007). This phenomenon explains many questions concerning the so-called idiopathic scoliosis and other deformities stated and unanswered till 1995. 
are cephalic presentations pregnancies with foetus lying of the left side of uterus (first position) and this position of the foetus influences future deformities. In cases of the "syndrome of contractures and deformities" the following may be observed frequently: an infantile scoliosis, torticollis and limitation of abduction of left hip (Fig. 2a, 2b, 2c) [Barlow 17, Golden 18, Cheng 19] .

\section{$2,3,5,6,14]$}

5. contracture (shortening) of abductor muscles and soft tissues of the right hip (acc to T. Karski), described as Haltungsschwäche ("weak posture") by Mau. With time, asymmetry in movement causes asymmetry during gait and loading; causing so-called idiopathic scoliosis (Karski 1995-2006) [9, 10, 11, 12, 13, 21, 22,

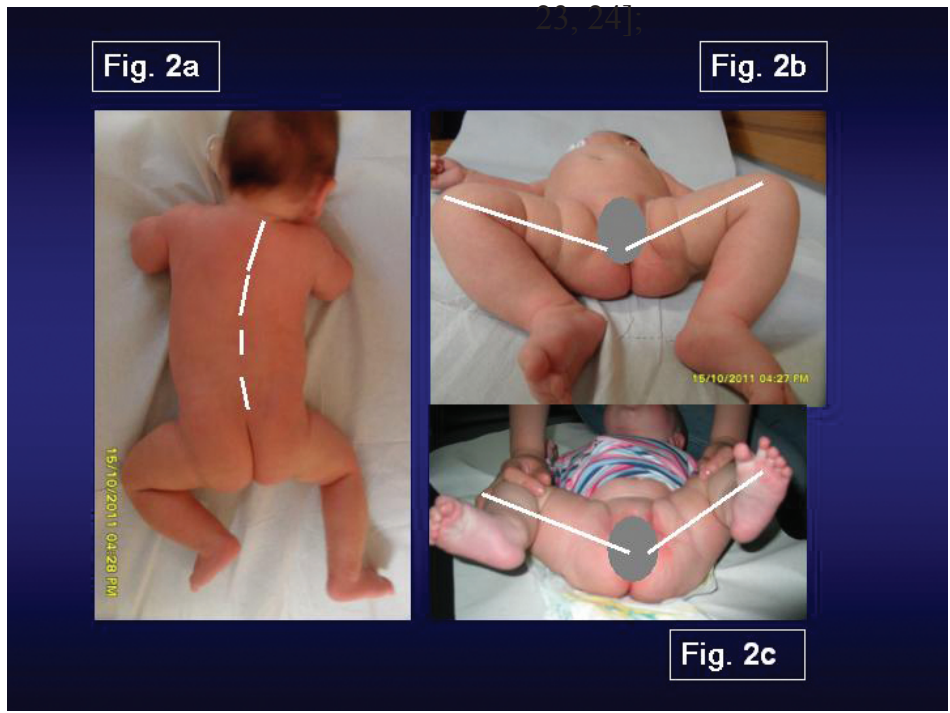

Fig. 2a, 2b Typical „syndrome of contractures and deformities”. Fig. 1a and 1b child Anna 1 month old. Changed axis of spine (scoliosis infantilis). Limited abduction of the left hip - first symptoms of dysplasia. Fig. 2c - child Kryspin 2 months old. Bigger limitation of abduction of left hip. Bigger dysplasia.

Clinical symptoms of the "syndrome of contractures" according to Mau (Fig. 1a, 1b, 2a, 2b, 2c):

1. scull deformity/plagiocephaly/,

2. torticollis muscularis (wry neck) $[8,12,15,16,18$, 19, 20],

3. scoliosis infantilis (infantile scoliosis) - other than idiopathic scoliosis [1, 9, 10, 13, 16, 21],

4. contracture (shortening) of adductor muscles of the left hip. Untreated contracture can lead to development of developmental hip dysplasia (DDH acc to Klisič) [1,
6. pelvic bone asymmetry - the oblique pelvis positioning visible during $\mathrm{X}$-ray examination for hip joint screening - [see above points $4 \& 5$ ];

7. Foot deformities - such as: pes equino-varus, pes equino-valgus, pes calcaneo-valgus [1, 15, 23, 24].

In 2006, the research conducted in Lublin allowed to add one more symptom to the series of symptoms enumerated above (T. Karski) and now we speak about "Syndrome of Contractures and Deformities" (SofCD). The studies proved that newborns and babies may have

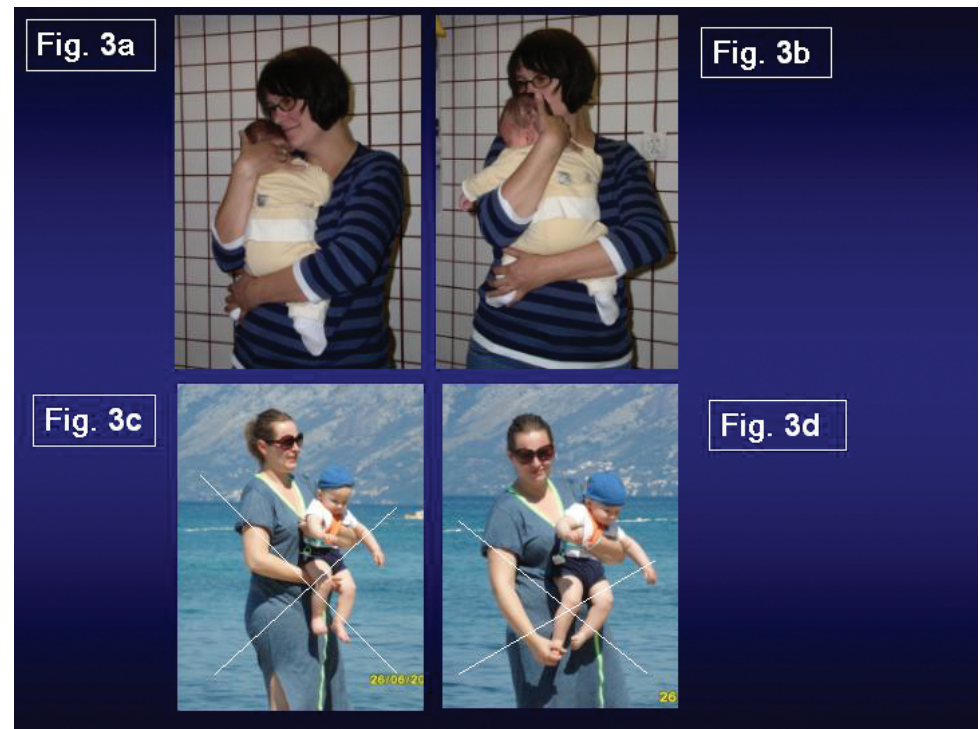

Fig. 3a, 3b Proper nurseling of the child. Hips in maximal abduction. Head and neck turned to the left side for treatment of left sided wry neck.

Fig. 3c, 3d Improper / incorrect nurseling of the child. Hips without abduction. Danger of the development of dysplasia. 
8. excessive shank deformity (crura vara) which later can lead under special conditions to Blount disease [25].

\section{Material}

In the years 2005 - 2013 authors examined 818 newborns and babies with the signs of the "syndrome of contractures". The control group included 212 children presented for examination, without signs of the "syndrome of contractures".

\section{Results}

\section{Hips}

The dysplasia of the hips can be connected with a/ Syndrome of Contractures and Deformities (So$\mathrm{fCD}$ ), with b/ laxity of joints and with $\mathrm{c} /$ disorders of central nerve system influencing muscular system in the hip region. The dysplasia of the hips in SofCD shows in babies as a deficit of abduction of hip, mostly on the left side (Fig. 2b, 2c). The physiological treatment of patients in this group of deformation is simply, easy and gives good results. In therapy, it is important to carry the child in full abduction and flexion of hips permanently, for as long as the baby requires carrying (Fig. $3 a, 3 b)$ as opposed to caring completely incorrectly that is without abduction of the hips. The wrong way of carrying is frequently recommended by "wrong-educated physiotherapies and orthopaedic surgeons (Fig. 3c, 3d). To help achieve this proper position of hips joints we use orthopaedic devices (Fig. 4a, 4b, 4c, 4d, 4e). or successful treatment and for full "restitutio ad integrum" a period of a few months or sometimes years is needed if the child suffers from dysplasia accompanied by laxity of joints. Our recommendation is not to allow the child walk before the age of 1 . Standing and walking before the age of 1 is a mistaken therapy and should be forbidden. If dysplasia of the hips in not cured by the time the child is 1 year, we suggest prolonged therapy of spongy triangle for walking or Weickert treasures model for walking (Fig. 4c).

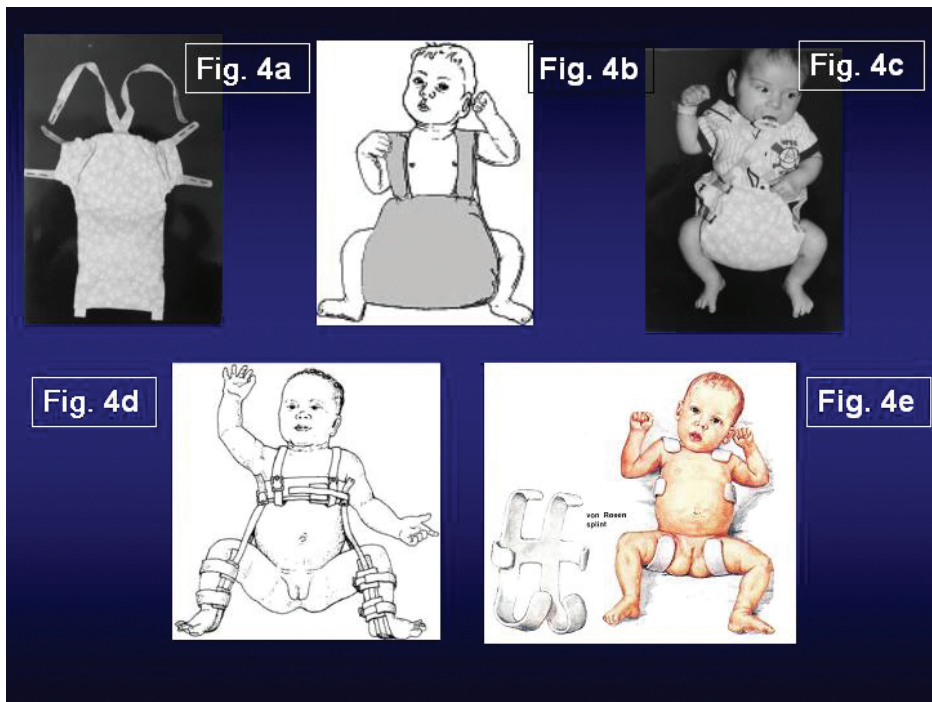

Fig. 4a, 4b, 4c, 4d, 4e Orthopaedic devices for the treatment of the hip dysplasia. Frejka pillow (4a. 4b), Weickert treasures (4c). Pavlik splints (4d), Von Rosen splint (4c).

\section{Neck}

Wry neck, called in Latin torticollis muscularis or torticollis myogenes, is a very common problem (Cheng JC and coll., Golden KA and coll., Kane AA and coll., Watson GH., Rogers GF. \& Mulliken J. ) in newborns and babies (6\% to $8 \%$ in Polish population) (Fig. 5a) There are three types of this deformity:

a/ connected with SofCD

b/ following traumatic delivery

c/ congenital wry neck with tumor neonaorum

The treatment of wry neck is frequently performed wrongly with the old method of physiotherapy (Fig. 5b, 5c). Consequently, the therapy never gives sufficient results. For proper treatment permanent "ro- tation and stretching" is advised (Fig. 5a, 6b, 7a, 7b, 8). This method of therapy was successfully introduced in Lublin in 1974 (T. Karski) for the treatment of children aged from 1 to $6-8$. It is worth mentioning that before 1974 we were operating 2-3 cases of wry neck each week in Paediatric Orthopaedic and Rehabilitation Department of the Medical University of Lublin. After 1974, only 2-3 cases were operated annually (data from the Department documents; Prof. T. Karski was the Head of this Department in years 1995 - 2009). 


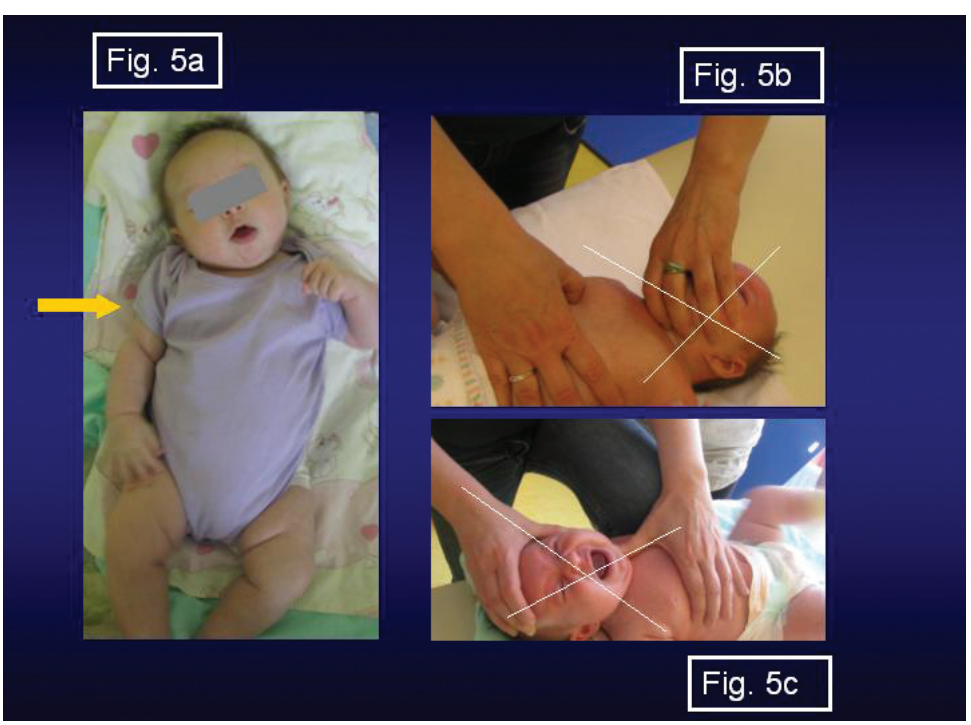

Fig. 5a, 5b, 5c Julia, 3 months old. Right sided wry neck (5a). Improper method of physiotherapy performed in one of Centres of Rehabilitation in Poland (5b, 5c). In result there is only paresis plexus brachalis - on the right (arrow). Such treatment for the wry neck brings no results.

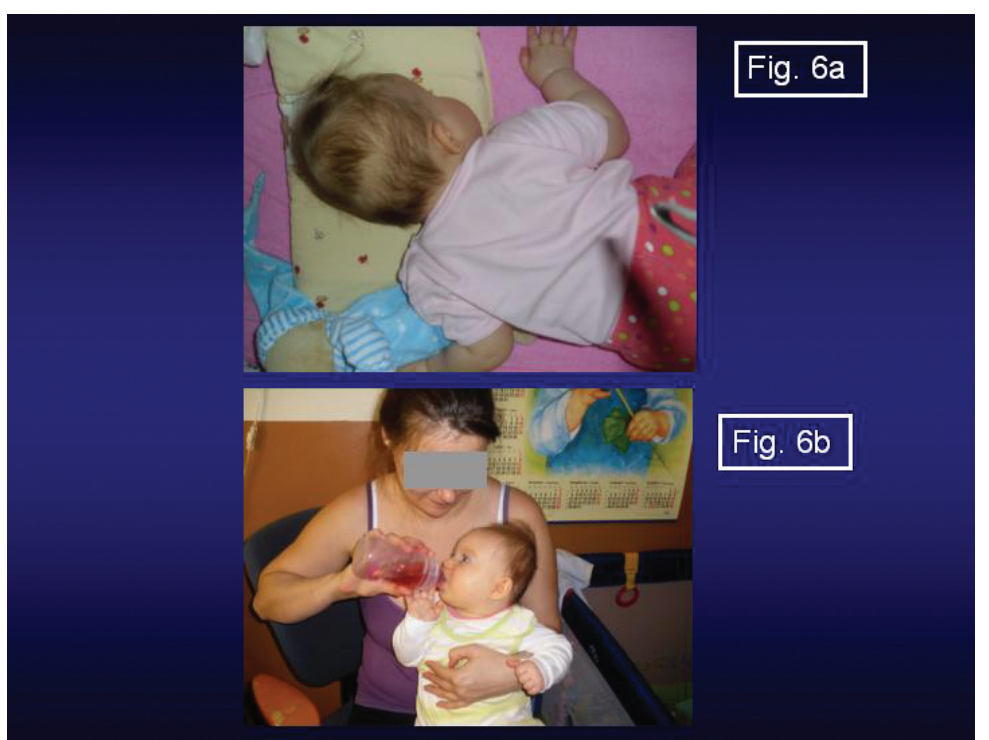

Fig. 6a, 6b Julia, 3 months old. Right sided wry neck. Proper method of physiotherapy in Lublin. Permanent stretching exercise of the head and neck by twisting to the right side and keeping of the upper right extremity in abduction and in external rotation. Such non-invasive therapy gives good results after the period of 8 month.

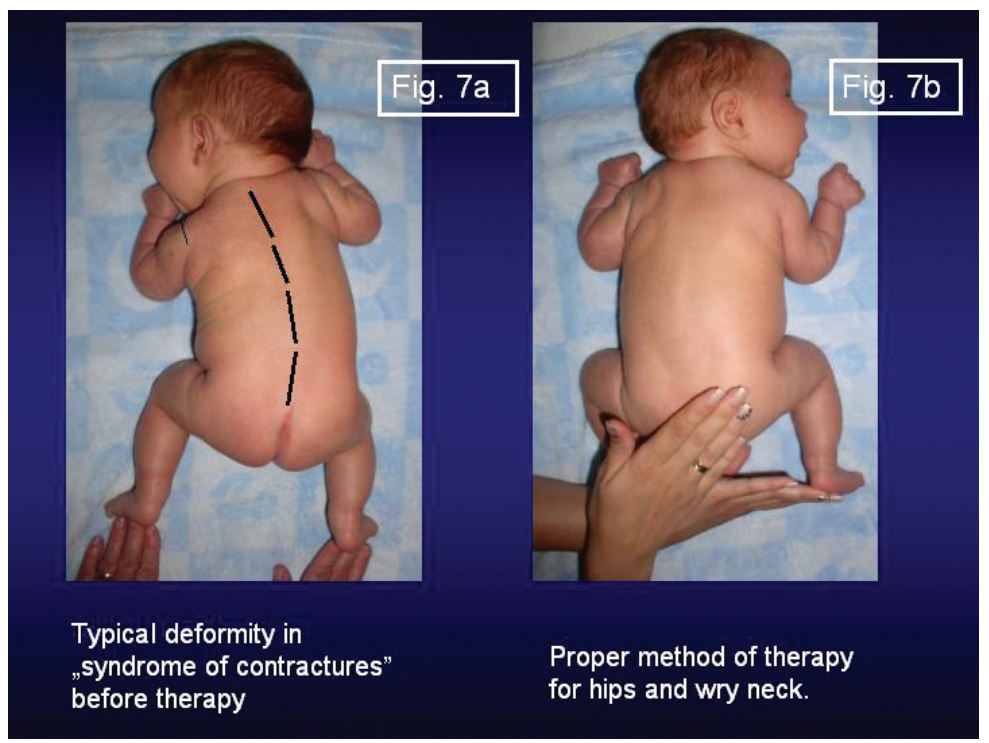

Fig. 7a, 7b Bartosz 6 weeks old. Typical „syndrome of contractures to the right side". Infantile scoliosis. Right sided wry neck. On the left - before treatment. On the right - during treatment (7b). Proper position for the hips, neck and spine. 


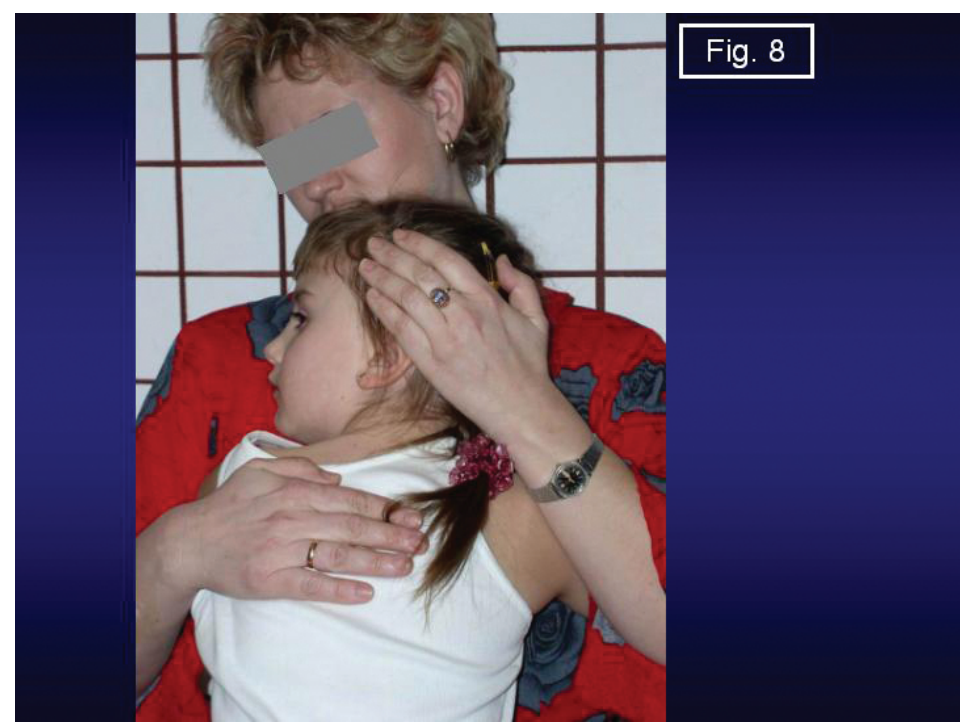

Fig. 8. Stretching-rotation treatment to the left side for left sided wry neck is a successful method even for older children, requiring a longer treatment period even $2-3$ years.

\section{Shank}

The varus deformity of shank was added to the Syndrome of Contractures and Deformities in 2006 - T. Karski (Fig, 9). When the varus of shank is bigger than "normal", the doctor should be alarmed. In result of adaptation to the space in uterus every newborn is born with varus deformity of the lower extremities. Conditions for the development of varus deformity called Blount disease are: a/ standing and walking before the age of 1 , and $b$ / insufficient vitamin D supply which may lead to easier development of the Blount disease, that is varus of shank at the knee level. Initially, the Blount disease in all cases is bilateral. In the following years one shank, mostly left one can get corrected spontaneously (Fig. 10a, 10b, 10c).

All cases of Blount disease till 1981 were operated. After long consideration, we concluded that the deformity develops according the Heuter Volkmann law. Yet, there are cases when the law does not apply or is not in function, the axis of shank is spontaneously corrected. Until 1981, for therapeutic reasons, we were advising parents not to allow the child to stand or walk for 2-3 months, but to carry the child. After this time the axis of leg comes to normal in all treated cases.

\section{Spine - scoliosis}

The biomechanical aetiology of scoliosis has been presented since 1995 (Karski T., Karski J. and coll., Kałakucki and coll.) and now (2014) is accepted in many countries and by many orthopaedic surgeons, rehabilitation doctors and physiotherapists. At the beginning, in development of the so-called idiopathic scoliosis there were: $1 /$ asymmetry in hips movements connected with SofCD, 2/ the influences connected with walking. Our explanation is as follows: the restricted movement of right hips is transmitted to the pelvis and to the spine and causes the rotation deformity and stiffness of spine, next the second cause works that is the permanent standing 'at ease' on the right leg. In the new classification of the socalled idiopathic scoliosis there are three group and four types of spine deformity (Fig. 11, 12, 13, 14). During the therapy of every types of scoliosis new proper exercises include only stretching, never strengthening.

\section{Discussion:}

Authors as Hensinger, Howorth, Green and Griffin, Dega and Vizkelety described some elements of SofC as plagiocephaly, dysplasia of the hip, feet contracture. The first who connected all those asymmetrical deformations into one syndrome was Prof. H. Mau. In our observations we confirmed presence of syndrome of contractures and its influence on locomotor system in children like dysplasia of the hip, Blount disease and wry neck, but also in youth and adults usually as painful contractures and deformations. Additionally we found influence of SofC in the biomechanical aetiology of the so-called idiopathic scoliosis.

\section{Conclusions.}

1/ Every paediatric orthopaedic surgeon and paediatric doctor as well every physiotherapist should be acquainted with the knowledge about the "Syndrome of Contractures and Deformities" (SofCD) according Prof. Hans Mau,

2/ Every newborn and baby with SofCD should be treated very early by proper nurseling and proper orthopaedic devices, older children should perform stretching exercises in order to reach symmetry of joints' movements. A surgery is sometimes necessary and performed in orthopaedic wards,

3/ Effective treatment of small children with "residual changes of SofCD", should be treated as an ef- 


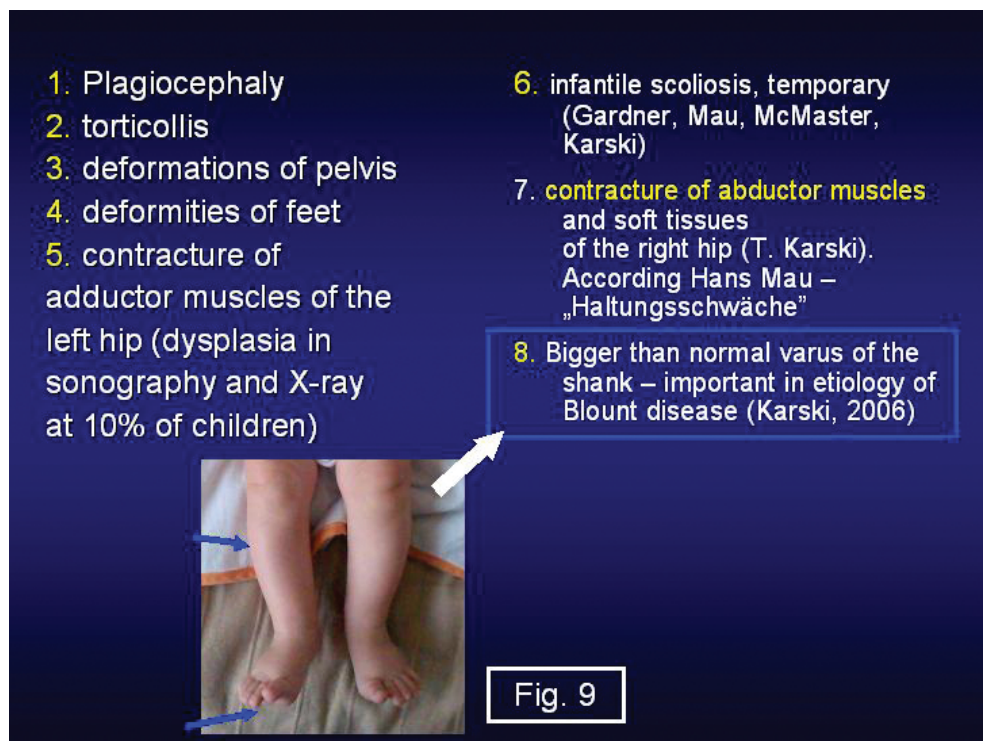

Fig. 9 Clinical symptoms of the „syndrome of contractures and deformities” according to H. Mau and T. Karski

fective prophylaxis of movement insufficiency of knees, hips and spine in adult age.

4/ The physiotherapy of problems of hips, neck, spine should aim at achieving the symmetry of position, symmetry of movement of joints and also symmetry of growth. Stretching exercises should be used as a treatment method for achieving the symmetry of the shortened side or part of body, and region of joints. Strengthening exercises proved to worsen the asymmetry!

5/ Additionally, thermotherapy, magnetic fields, biodynamic (diadymanic), laser, massage can be used for the treatment.

\section{References:}

1. Mau H. Aetiopathogenese von Skoliose, Hüftdysplasie und Schiefhals in Säuglingsalter, Zeitschrift $\mathrm{f}$. Orthop. 1979, 5, 6-1 - 605

2. Hensinger R.N. Congenital dislocation of the hip. Clinical Symp. 1979, 31

3 . Howorth B. The etiology of congenital dislocation of the hip, Clic. Orthop. 1977, 29, $164-179$

4. Green N.E., Griffin P.P. Hip dysplasia associated with abduction contracture of the contra lateral hip, J.B.J.S. 1982, 63-A, $1273-1281$

5. Dega W. Badania $\mathrm{z}$ dziedziny etiologii wrodzonego zwichnięcia biodra. Chir. Narz. Ruchu, 1932, 144

6. Vizkelety, T.: Wspolczesne problemy wrodzonego zwichniecia i dysplazji biodra. [Current problems of congenital hip dislocation and dysplasia]. Chirurgia narzadow ruchu i ortopedia polska 1981. Volume: 46 Issue: 5 Pages: 429-34

7. Glauber, A., Vizkelety T: Results of treating congenital dislocation of hip with strap-sling after Pavlik. Zeitschrift fur Orthopadie und Ihre Grenzgebiete 1972, Volume: 110 Issue: 1 Pages: $108-\&$
8. Kane AA, Mitchell LE, Craven KP, et al. Observations on a recent increase in plagiocephaly without synostosis. Pediatrics 1996;97:877-85.

9. Karski J., Karski T., Tarczyńska M., Kałakucki J. Zespół przykurczów u noworodków i niemowląt wg prof. Hansa Mau w wyjaśnieniu ,geografii” i klinicznych cech skolioz tzw. idiopatycznych. Ortop. Traumatol. Rehabil. 2004 vol. 6 Suppl. 1, s. 31.

10. Karski J., Karski T., Kandzierski G., Tarczyńska M., Kałakucki J., Latalski M. „Zespół przykurczów" u noworodków i niemowląt wg prof. Hansa Mau w wyjaśnieniu ,geografii” i niektórych klinicznych cech skolioz tzw. idiopatycznych. („Contracture syndrome" in newborns and infants according to Prof. Hans Mau as an explanation of the „geography” and certain clinical features of idiopathic scoliosis). Ortop. Traumatol. Rehabil. 2005 vol. 7 nr 1, s. 23-27, bibliogr. sum.

11. Karski J., Kalakucki J., Karski T., Dlugosz M. „Syndrome of contractures” (according to Mau) with the abduction contracture of the right hip as causative factor for development of the so-called idiopathic scoliosis. („Syndrom kontraktur” (podle Mau) s abdukční kontrakturou pravého kyčelního kloubu jako př́ičinného faktoru vývoje tzv. idiopatické skoliózy). Pohyb. Ustr. / Czech Republic, 2006 R. 13 č. 1/2, s. 81-88, bibliogr. poz. 21.

12. Karski J., Karski T., Kędzierski Z. „Syndrome of contractures and deformities" in newborns and infants according Mau - and its influence for secondary deformities of movement apparatus in babies, youth and adults. Pohyb. Ustr. 2013 R. 20 č. $3 / 4$ suppl., s. 315 317

13. Karski T., Frelek-Karska M., Karski J., Madej J., Kalakucki J.: „Zespół przykurczów” u noworodków i niemowląt przyczyną odległych dysfunkcji narządu ruchu w tym tzw. skolioz idiopatycznych. Wykry- 


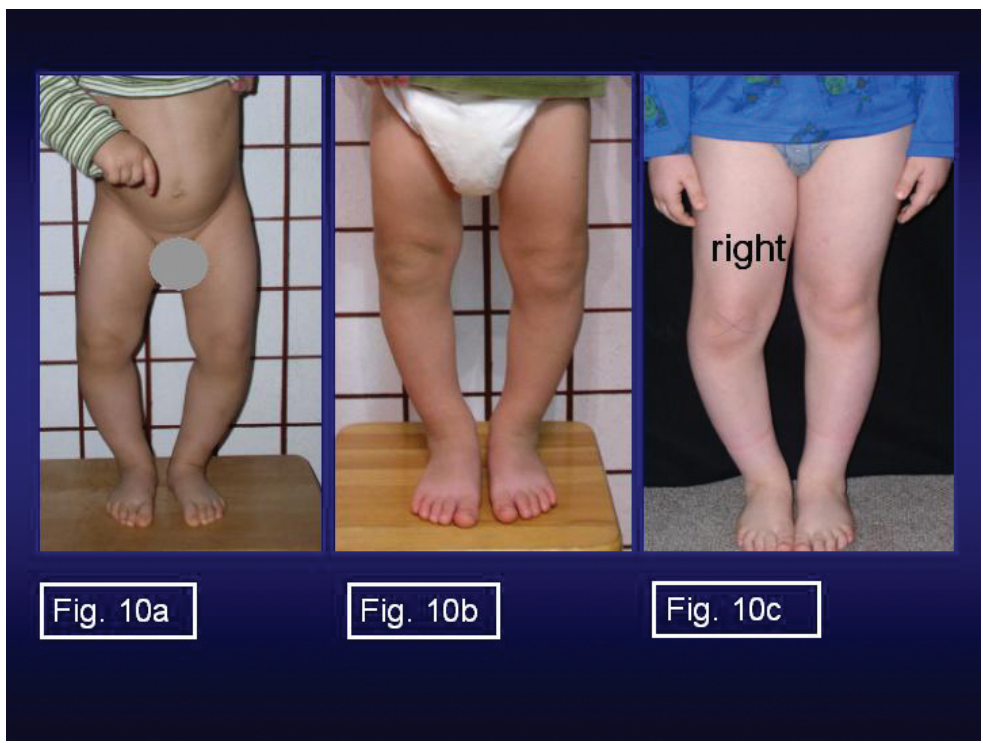

Fig. 10a, 10b, 10c. Varus deformity of shank (crura vara). On the left (Fig. 10a) typical Blount disease, In the middle (Fig. 10b) Blount disease accompanied by rickets. On the right (Fig. 10c) one-side Blount disease. Left leg - self correction. Treatment of children aged $1-3$ only by physiotherapy (see the article above). Older children - surgery.

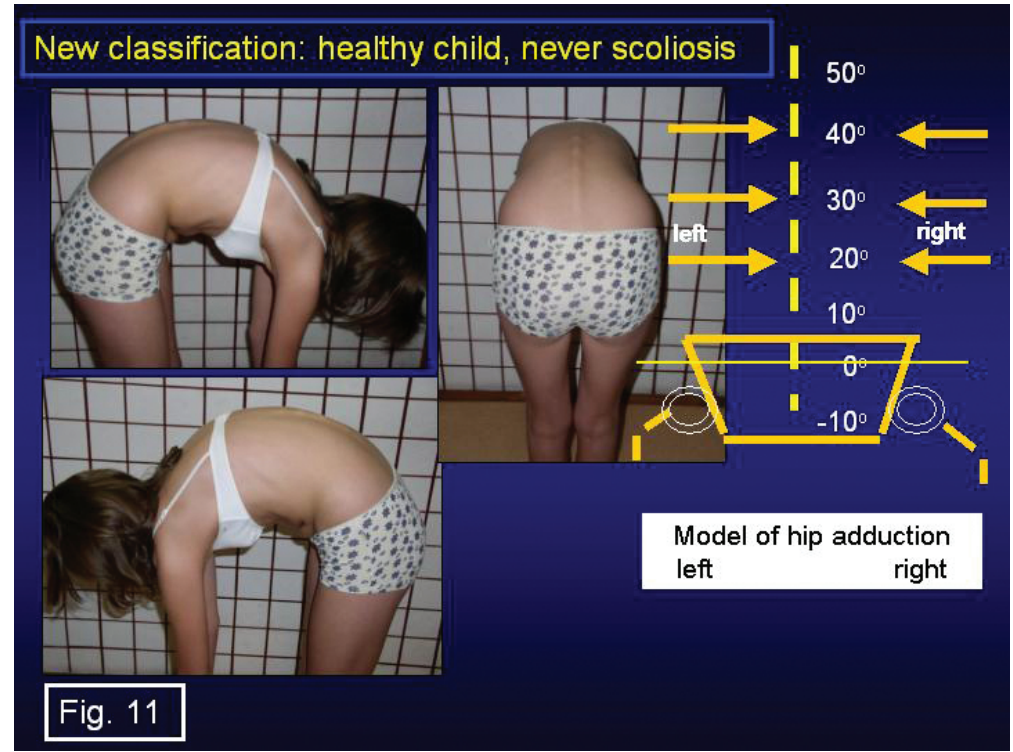

Fig. 11. A healthy child. No deformation of spine. Symmetry of hips and movements. Symmetry of the movement of the trunk both the left and the right side during gait. Symmetry of standing time left vs. right leg.

wanie zagrożeń nieprawidłowego rozwoju kręgosłupa i zasady nowej profilaktyki skolioz. (The syndrome of contractures' at newborns and babies as a cause of dysfunctions of skeletal system and among others of the socalled idiotaphic scoliosis. The discovery of the danger of the oncoming scoliosis. Rules of new prophylactics.) W: Międzynarodowa Konferencja Naukowa: „Uwarunkowania rozwoju sprawności i zdrowia”. Częstochowa, 10-11 grudnia 2001. Progr. i streszcz, s. 11-12.

14. Karski T., Karski J., Kałakucki J. Minimal incongruence of the hip joint at youth and adults treated and not-treated because of DDH in baby period. W: Second Annual International Conference SICOT/SIROT 2003. Cairo, September 10-13, 2003. Abstr, [b. pag.] SFS8-H
15. Kałakucki J., Karski J., Długosz M., Karski T. „Science and opinion - knowledge and ignorance (Hippocrates) on examples in pediatric orthopedics". Wry neck (torticollis myogenes), Perthes disease, ,anterior tilt of pelvis" in children and youth and ,spine pain syndrome" in adults (P. 3). Pohyb. Ustr. / Czech Republic, 2008 R. 16 č. 3/4 suppl., s. 283-286.

16. Watson GH. Relation between side of plagiocephaly, dislocation of hip, scoliosis, ba tears, and sternomastoid tumours. Arch Dis Child 1971;46:203-10.

17. Barlow T.G. Early diagnosis and treatment of congenital dislocation of the hip, J..B.J.S. 962, 44-B (2), $292-3012$

18. Golden KA, Beals SP, Littlefield TR, et al. 


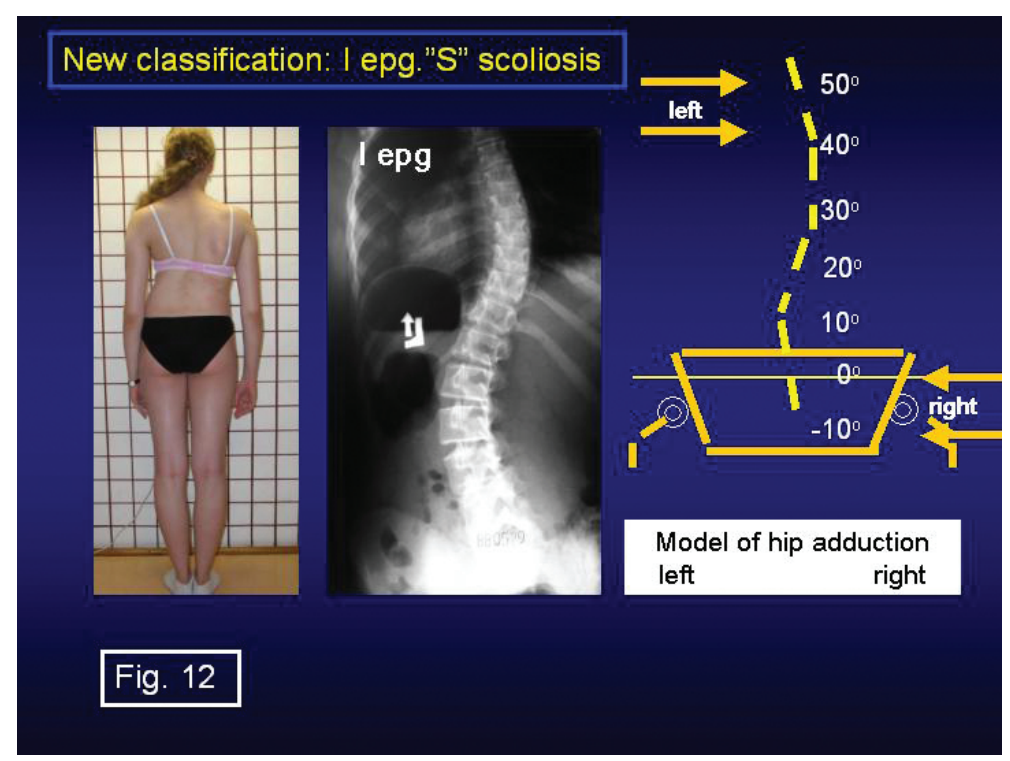

Fig. 12 „S” scoliosis in I epg, 3D, primary double curves - connected with gait \& standing 'at ease' on right leg. First rotation deformity, next curves. Stiffness of spine. Progression.

Sternocleidomastoid imbalance versus congenital muscular torticollis: their relationship to positional plagiocephaly. Cleft Palate Craniofac J 1999;36:256-61.

19. Cheng JC, Tang SP, Chen TM, et al. The clinical presentation and outcome of treatment of congenital muscular torticollis in infants: a study of 1,086 cases. J Pediatr. Surg. 2000;35:1091-6.

20. Rogers GF, Mulliken JB. The significance of torticollis in deformational posterior plagiocephaly [abstract]. Proceedings of the Tenth International Congress of the International Society of Craniofacial Surgery $2003 ; 61$.

21. Karski T., Kałakucki J., Karski J. „Syndrome of contractures" (according to Mau) with the abduction contracture of the right hip as causative factor for development of the so-called idiopathic scoliosis.W: Technology and informatics vol. 123 Research into spinal deformities 5 Ed. D. Uyttendaele, P.H. Dangerfield, Washington, 2006, IOS Press, s. 34-39, bibliogr. poz. 21.

22. Karski T., Kałakucki J., Karski J. Relationship of ,syndrome of contractures" in newborns with the development of the so-called idiopathic scoliosis, World J. Pediatr. / China, 2007 vol. 3 nr 4, s. 254-259, bibliogr. poz. 38.

23. Karski J., Karski T. „Zespół przykurczów” u noworodków i niemowląt przyczyną odległych dysfunkcji narządu ruchu w tym skolioz tzw. idiopatycznych. Wykrywanie zagrożeń oraz zasady profilaktyki przez zabiegi fizjoterapeutyczne. (,Syndrome of contractures" in newborns and babies as a cause of deformities in movement apparatus and in etiology of the so-called idiopathic scoliosis in next years of life. New screening and treatment by physiotherapy.) Zesz. Nauk. WSSP 2012 t. 15, s. 11-25, bibliogr. poz. 43, sum.

24. Karski T: www.ortopedia.karski.lublin.pl
25. Karski J., Długosz M., Kałakucki J., Karski T. Science and opinion - knowledge and ignorance (Hippocrates) on examples in pediatric orthopedics - Blount disease, X-knee deformity, chronic pain in shank and foot by owners of small cars (P. 2). Pohyb. Ustr. 2008 R. 16 č. 3/4 suppl., s. 286-288.

Acknowledgement: We would like to express our thanks to MA Katarzyna Karska for correction of English text in this paper.

\section{Correspondence address:}

Jacek Karski MD PhD

Harcerska 35

20-805 Lublin

Poland

jkarski@vp.pl

tmkarski@gmail.com 


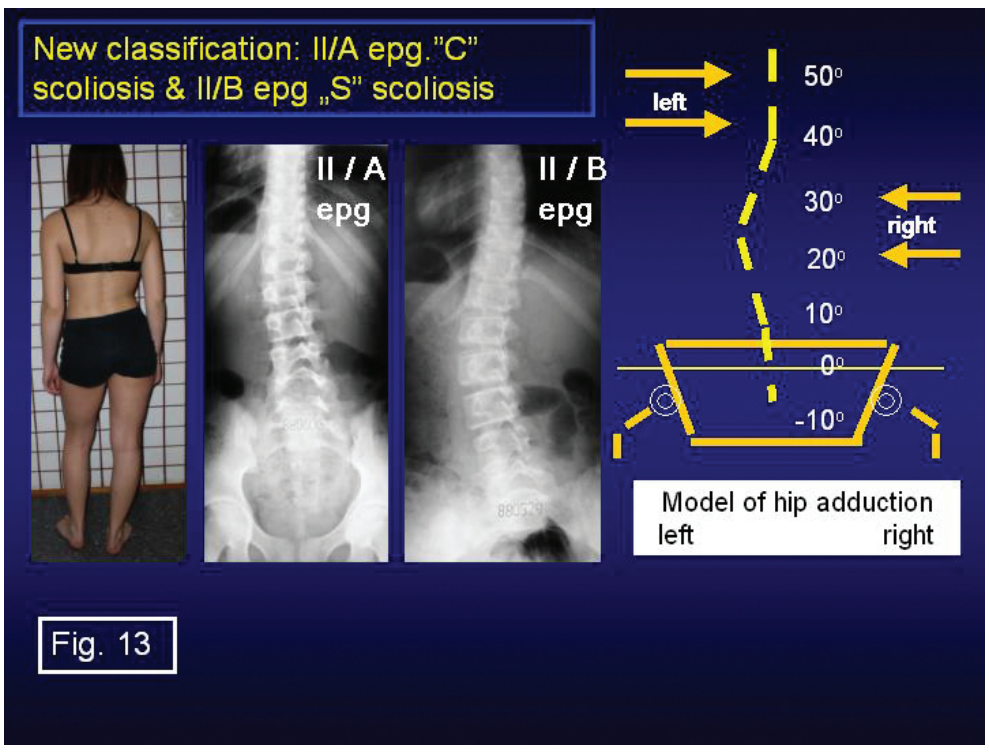

Fig. 13 "C" scoliosis - II / A epg, 1D, connected with standing 'at ease' on the right leg, „S” scol. in II / B, 2D or mix / flexible spine. Thoracic curve - secondary. Aetiology for „S” II/B: standing 'at ease' on the right leg, additional laxity of joints and / or wrong exercises in therapy. No progression or small.

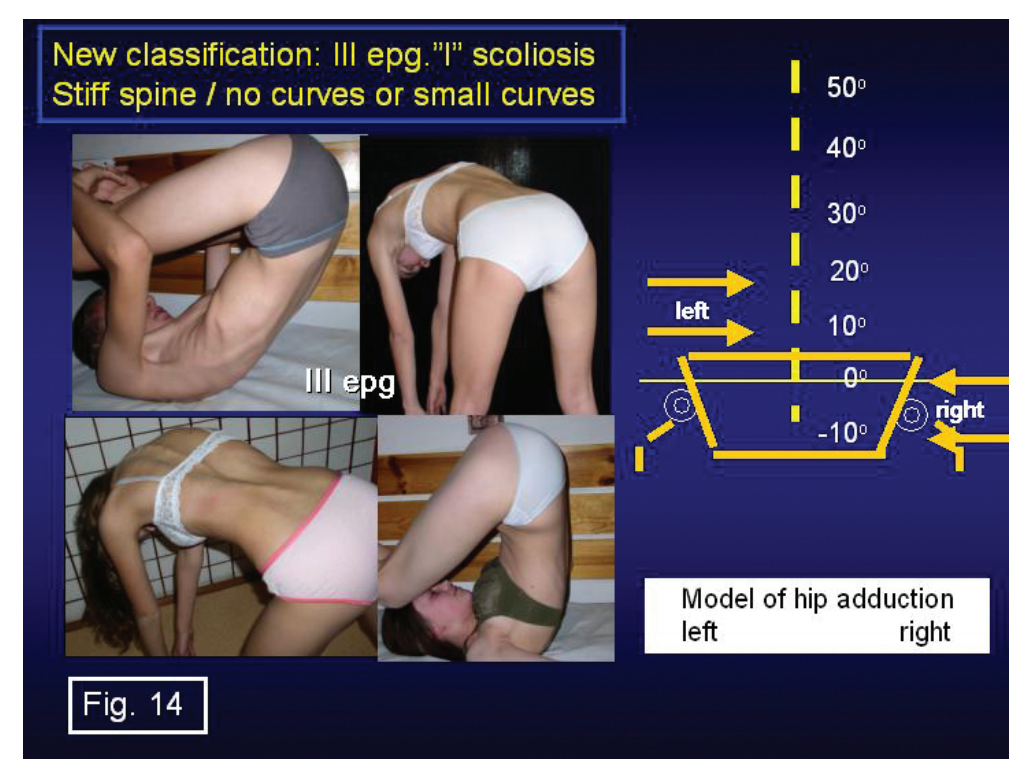

Fig. 14. „I” scoliosis III epg - connected with gait only. 2D or mix. Stiffness of spine. Small curves or no curves. In adulthood - pain. No progression. 
